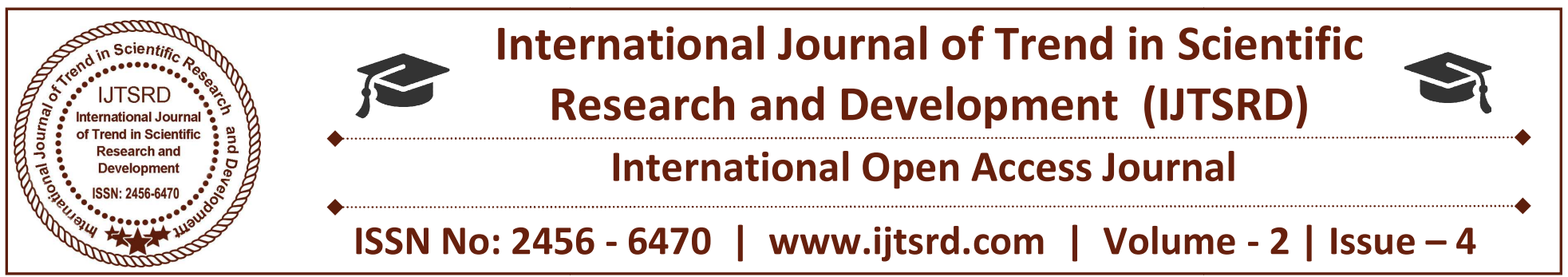

\title{
Effect of Fertigation on Growth, Yield and Quality of Tomato (Lycopersicon Esculentum MILL. VAR. COTH2)
}

\author{
Dr. R. Pandiyan, Dr. V. A. Sathiyamurthy, Dr. L. Pugalenthi, Dr. R. Nagarajan \\ Department of Vegetable Crops, Horticultural College and Research Institute, Agricultural University, \\ Coimbatore, Tamil Nadu, India
}

\section{ABSTRACT}

Drip irrigation provides an efficient method of fertilizer delivery and allows precise timing and uniform distribution of applied nutrients. Fertilizer application through drip irrigation (fertigation) can reduce fertilizer usage and minimize ground water pollution due to fertilizer leaching from excessive irrigation. Fertigation events can be scheduled as often as irrigation, up to several times per season. Optimum fertigation interval for drip-irrigated crops in general and for tomato in particular, is meager. An experiment to know the effect of fertigation on growth, yield and quality of Tomato.Var COTH 2 was carried out during the year 2011 to 2013 at the Department of Vegetable Crops, Horticultural College and Research Institute, Tamil Nadu Agricultural University, Coimbatore. The experiment was laid out in randomized block design with seven treatments and replicated four times. The treatment combination includes raised bed cultivation, drip irrigation, fertigation, plastic mulch, foliar spray of WSF, micronutrients and seedlings raised in trays. The results revealed that the treatment combination raised bed + Drip irrigation + Plastic mulch + Fertigation + Foliar spray of WSF (19:19:19@10g/lit. 5 times) + Mixture of all micronutrients + seedling raised in tray (T1) recorded the highest plant height $(105.6 \mathrm{~cm})$, no. of fruits per plant (46.8), fruit weight $(60.6 \mathrm{~g})$, yield per plot $(94.0 \mathrm{~kg})$ and recorded the highest yield of $743.9 \mathrm{q} / \mathrm{ha}$ with the $\mathrm{BC}$ ratio of 3.07 While the farmers practices, recorded the fruit yield of 540.8 $\mathrm{q} /$ ha with the $\mathrm{BC}$ ratio of 2.70 . Therefore (T1) raised bed + drip irrigation + plastic mulch + fertigation + foliar spray of WSF (19:19:19@10 g/lit. 5 times) + mixture of all micronutrients + seedling raised in pro trays can be recommended for getting increased growth, flowering and the highest yield for tomato under Rabi cultivation.

Key words: Tomato hybrid COTH 2, fertigation, mulching, foliar application, Micro nutrients, growth, Yield

\section{INTRODUCTION}

Technologies such as drip irrigation and fertigation can improve WUE and decrease salinization while maintaining or increasing yields. Fertigation is an agricultural water management technology that supplies water and fertilizer simultaneously in a drip irrigation system, feeding a crop by injecting soluble fertilizers into water and then transporting them into the root zone. Fertigation, which can improve the efficiency of irrigation water and fertilizer, is a new fertilization method of precision agriculture. In the late 1970 s, the use of fertigation technology was widespread in China, particularly in the North and Northwest regions, where water shortage is very serious. In drip fertigation systems, which combine drip irrigation with fertilizer application, the fruit yield of tomato was $20-30 \%$ higher in drip fertigation than in furrow irrigation. It is well known that water and fertilizer are the two main factors limiting vegetable and crop production in arid and semiarid regions. Tomato is one of the most popular and widely grown vegetables in the world. The first reason for this is that tomatoes are beneficial to our heath and are good sources of provitamins, $\beta$ carotene, and vitamin $\mathrm{C}$. The second reason is that tomatoes are particularly rich sources of lycopene, 
which is a very powerful antioxidant and helps prevent the development of many forms of cancer. Hence, this vegetable is gaining importance in both developing and developed countries, and efforts are being made to improve the quality and quantity of tomato production. Of course, water supply is important for tomato yield quantity and quality. Increasing the water supply increases fruit yield but significantly reduces the brix, lycopene, and total polyphenol contents of fruits; the ascorbic acid content is significantly higher under optimum water supply conditions .Water stress is one of the most important environmental factors that regulate plant growth and development and limit plant production

Although India has the largest irrigation network in the world; its irrigation efficiency has not been more than 40 per cent. Bringing more area under irrigation will largely depend upon efficient use of water. In this context, micro irrigation has most significant role to achieve not only higher productivity and water use efficiency but also to have sustainability with economic use and productivity. Fertigation is the process wherein fertilizer is applied through an efficient irrigation system like drip. In fertigation, nutrient use efficiency could be as high as 90 per cent compared to 40 to 60 per cent in conventional methods (Solaimalai et al., 2005). The amount of fertilizer lost through leaching can be as low as 10 per cent in fertigation whereas it is 50 per cent in the traditional system. Adoption of micro-irrigation systems may help to increase the irrigated area, productivity of crops and water use efficiency. Drip irrigation has proved its superiority over other methods owing to direct application of water in the root zone. Indiscriminate use of water through Conventional irrigation system with only 60 per cent application efficiency is causing serious threat to available ground water resources. Drip irrigation can play a vital role in maximizing water use efficiency. Low nitrogen use efficiency in conventional method of irrigation is also a major reason for low productivity of crops. Drip irrigation is at present economically feasible in high value crops. The use efficiency of these key inputs is currently very low in India leading to a lot of problems such as low crop productivity, degradation of soil health and increased environmental pollution apart from the wastage of substantial quantity of these costly and scarce inputs, increasing the efficiency of water and fertilizer use can itself go a long way in meeting the growing demand for food and other plant products consequent to rapidly escalating population (Koo, 1981). The shrinking land, man ratio, water, increasing fertilizer prices, haunting energy crisis, wide spread population and fast degradation of natural resources further emphasise the need for improved water and fertilizer use efficiency (Dass, 1985). Drip fertigation optimize the use of water and fertilizer enabling to harness high crop yield, simultaneously ensuring a healthy soil and environment. The drip fertigation technology encompasses the application of solid and liquid mineral fertilizers through drip irrigation system thus, supplying a nutrient containing irrigation water to crops.

\section{MATERIALS AND METHODS}

A field experiment was carried out to study the "Effect of fertigation on growth, yield and quality of Tomato (Lycopersicon esculantus L.). Var. COTH2 during Rabi 2011 to2013 at the Department of Vegetable Crops, Horticultural College and Research Institute, Tamil Nadu Agricultural University, Coimbatore. The experiment was laid out with seven treatments and with four replications. The experiment in tomato was conducted during the rabi season of every year and the spacing adopted was $60 \times 60 \mathrm{~cm}$. Twenty five days old seedlings were transplanted in the raised bed with the spacing of $60 \times 60 \mathrm{~cm}$. From the recommended dose of fertilizers 200:250:250 kg NPK /ha, $75 \%$ of $\mathrm{P}_{2} \mathrm{O}_{5}$ was applied in the form of superphosphate as basal. And the remaining fertilizers were applied through drip and fertigation. The treatment combinations for tomato are 
International Journal of Trend in Scientific Research and Development (IJTSRD) ISSN: 2456-6470

\begin{tabular}{|c|c|}
\hline T1: & $\begin{array}{l}\text { Raised bed + Drip irrigation + Plastic mulch + Fertigation + Foliar spray of WSF (19:19:19 @10g/lit. } 5 \\
\text { times) + Mixture of all micronutrients + seedling raised in pro tray }\end{array}$ \\
\hline $\mathrm{T} 2$ & $\begin{array}{l}\text { Raised bed + Drip irrigation + Plastic mulch + Fertigation + Foliar spray of WSF (19:19:19@10g/lit. } 5 \\
\text { times) + Mixture of all micronutrients }\end{array}$ \\
\hline T3: & $\begin{array}{l}\text { Raised bed + Drip irrigation + Plastic mulch + Fertigation + Foliar spray of WSF (19:19:19@10g/lit. } 5 \\
\text { times) + seedling raised in pro tray }\end{array}$ \\
\hline T4: & $\begin{array}{l}\text { Raised bed }+ \text { Drip irrigation }+ \text { Plastic mulch }+ \text { Fertigation }+ \text { Mixture of all micronutrients }+ \text { seedling raised in } \\
\text { pro tray }\end{array}$ \\
\hline T5: & $\begin{array}{l}\text { Raised bed + Drip irrigation + Plastic mulch + Foliar spray of WSF (19:19:19@10g/lit. } 5 \text { times) + Mixture } \\
\text { of all micronutrients+ seedling raised in pro tray }\end{array}$ \\
\hline T6 & $\begin{array}{l}\text { Raised bed + Drip irrigation + Fertigation + Foliar spray of WSF (19:19:19@10g/lit. } 5 \text { times })+ \text { Mixture of } \\
\text { all micronutrients+ seedling raised in pro tray }\end{array}$ \\
\hline $\mathrm{T} 7$ & Farmer's practices \\
\hline
\end{tabular}

The results of the three-year trials were presented in the Table 1, 2, 3 and the pooled mean data are presented in Table 4.

\section{RESULTS AND DISCUSSION}

The results obtained from the present investigation are summarized below.Effect of precision farming treatments on yield of tomato during rabi 2011(table1).Among the treatments, the treatment combination raised bed + Drip irrigation + Plastic mulch + Fertigation + Foliar spray of WSF (19:19:19 (1) $10 \mathrm{~g} /$ lit. 5 times) + Mixture of all micronutrients+ seedling raised in pro tray (T1) recorded the highest plant height $(105.6 \mathrm{~cm})$, no. of fruits per plant $(46.8)$, fruit weight $(60.6 \mathrm{~g})$, yield per plot $(94.0 \mathrm{~kg})$ and the highest yield per ha $(725.7 \mathrm{q})$ when compared to control (Farmers practice T7) (523.1 q/ha). The results revealed that the Effect of precision farming treatments on yield of tomato during kharif 2012 (table.2).Among the treatments, the treatment combination of raised bed + drip irrigation + plastic mulch + fertigation + foliar spray of WSF (19:19:19 (@) $10 \mathrm{~g} / \mathrm{lit} .5$ times $)+$ Mixture of all micronutrients + seedlings raised in pro trays(T1) recorded the highest plant height (106.5), fruits per plant (46.4 g), fruit weight $(62.7 \mathrm{~g})$, plot yield $(83.8 \mathrm{~kg})$ and the highest yield per ha $(776.0 \mathrm{t})$ when compared to farmers practice (T7) which recorded the yield of 563.0 $\mathrm{t} / \mathrm{ha}$. The results revealed that the Effect of precision farming treatments on yield of tomato during kharif 2013(table.3).Among the treatments, the treatment combination of raised bed + drip irrigation + plastic mulch + fertigation + foliar spray of WSF (19:19:19 @ $10 \mathrm{~g} / \mathrm{lit}$. 5 times) + Mixture of all micronutrients + seedlings raised in pro trays (T1) recorded the highest plant height (104.4), fruits per plant (46.5 g), fruit weight $(61.7 \mathrm{~g})$, plot yield $(81.1 \mathrm{~kg})$ and the highest yield per ha (729.9 t) when compared to farmers practice (T7) which recorded the yield of 536.4 $\mathrm{t} /$ ha. The pooled data of three years trials revealed thatin tomato $\mathrm{cv}$. COTH 2, the treatment combination of raised bed + drip irrigation + plastic mulch $(30$ micron) + fertigation with water soluble fertilizers + foliar spray of WSF (19:19:19@10g/lit. 5 times from 45 days after transplanting) + mixture of all micronutrients + seedling raised in pro-tray recorded the highest yield of $743.9 \mathrm{q} /$ ha with the $\mathrm{BC}$ ratio of 3.07 While the farmers practices, recorded the fruit yield of $540.8 \mathrm{q} / \mathrm{ha}$ with the $\mathrm{BC}$ ratio of 2.70 .

Fertilizer savings through fertigation can be to the tune of 25-50 per cent (Haynes, 1985). Fertigation reduces the nutrient loss that would normally occur with conventional methods of fertilizer application and thus, permits better availability and uptake of nutrients by the crops, leading to higher yield with high fertilizer use efficiency. Nitrogen use efficiency (NUE) for red chilli fruit production decreased with increasing $\mathrm{N}$ upto $240 \mathrm{Kg} \mathrm{ha}^{-1}$ (Payero et al., 1990). Clark et al. (1991) reported that fertigation resulted in reduced water and fertilizer application as compared to those associated with conventional irrigation method. The increase in yield and its quality together with the improved water and fertilizer efficiency, make fertigation an attractive technology in modern irrigated agriculture (Papadopoulos, 1992). Drip fertigation provides an efficient method of fertilizer delivery and if properly managed, reduce overall fertilizer application rate and minimize the adverse environmental impact (Hartz and Hochmuth, 1996). Unlike surface irrigation and conventional fertilizer application, fertigation makes uniform distribution of nutrient solution in the root zone and thereby increases the fertilizer use efficiency, since the uptake of nutrients by the plant roots depends on their availability to the root system (Rao, 1996). Satisha (1997) found that the efficiency of phosphorus fertilizer could beincreased upto 45 per cent by trickle 
irrigation compared to only 10-20 per cent achievable by conventional method of application. Fertigation enhanced the overall root activity, improved the mobility of nutritive elements and their uptake, as well as reducing the contamination of surface and ground water. The fertigation technique is used mainly with N and K fertilizers (Taha, 1999). Drip irrigation has gained wide spread popularity as an efficient method for fertigation because bothtime and rate of nutrients can be controlled to meet the requirements of a crop at each physiological growth stage (Bar-Yosef, 1997). In tomato, the yield increased linearly upto $50 \mathrm{~kg} \mathrm{P}$ ha-1 application through broadcast. But in fertigated treatment it was $25 \mathrm{~kg} \mathrm{P}$ ha- 1 and 50 per cent of $\mathrm{P}$ was savedthrough fertigation due to increased FUE (Carrijo and Hochmuth, 2000). Fertigation permits improved efficiency of irrigation and nutrient use and reduces application costs. It improves plant growth and nutrient uptake and limits nutrient losses (Anonymous, 2005). A properly designed drip fertigation system delivers water and nutrients at a rate, duration and frequency, so as to maximize crop water andnutrient uptake, while minimizing leaching of nutrients and chemicals from the root zone of gricultural fields (Gardenas et al., 2005).

Bracy et al. (1995) registered significant increase in bell pepper yield in response to fertigation of $\mathrm{N}$ and $\mathrm{K}$ through drip irrigation significantly higher tomato fruit yield (107.3 tha-1) was obtained by fertigation which was 42.3 per cent higher than band placement. The capsicum plants that received fertigation had higher leaf NO3 concentration and yielded more than three times those plants that received fertilizer prior to planting (Obreza and Vavrina, 1995). Deek et al. (1997) reported that $\mathrm{N}$ fertigation through drip irrigation with ten equal splits and equal time of intervals resulted in high tomato yield of $47.1 \mathrm{t}$ ha- 1 as compared to fertigation with three equal splits and equal time intervals (35.8 t ha-1). Natrajan et al. (2002) ravealed that in tomato fertigation with 250:250:250 kg per hectare water soluble fertilizer has recorded highest yield of 102 tonnes per hectare. (Singandhupe et al., 2002). Ajmalkhan (2000) stated that fertigation of recommended dose of nitrogen as urea and $\mathrm{K} 2 \mathrm{O}$ as muriate of potash applied in 15 equal splits at eight days interval starting from 8 DAP to 120 DAP through drip system recorded higher tomato yield as compared to surface irrigation with conventional method of fertilizer application on sandy loam soil at Madurai (TNAU) in Tamil Nadu.

The yield and yield attributes in tomato such as number of fruits per plant (40.71), average fruit weight $(60.89 \mathrm{~g})$, yield per plant, plot and hectare $(2.36 \mathrm{~kg}, 53.84 \mathrm{~kg}$ and 56.98 tonnes, respectively) were maximum in fertigation 100 per cent recommended NPK through drip (Imamsaheb et al., 2011).

(Hugar, 1996). Sivanappan (1996) reported that an extra income of Rs. 49,280 ha-1 could be obtained under drip irrigation in tomato over surface irrigation and the payback period of drip system cost was only six months. Asokaraja (1998) recorded higher benefit cost ratio of 9.89 due to drip irrigation than surface irrigation (5.44) in tomato. The cost of micro irrigation system and optimization was performed to assess minimum input cost of tomato, considering the advent of mechanically moved portable dripsets, with every second day irrigation approximately 50 per cent saving on initial investment of drip set can be achievedas the same set will irrigate double the area

(Dalvi et al., 1999). Khan et al. (1999) found that drip fertigation with 100 per cent water soluble fertilizers in potato has recorded higher net profit of Rs. 38,742 ha-1 when compared to dripfertigation with 100 per cent normal fertilizer (Rs. 33,604 ha-1) and furrow irrigation with 100 per cent normal fertilizer (Rs. 32,583 ha-1). Application of water soluble fertilizers at higher level (300: 300: $300 \mathrm{~kg} \mathrm{NPK} / \mathrm{ha}$ ) produced excellent quality fruits and resulted in higher profit of Rs. 22,930 per year with a cost benefit: ratio of 1:3.89 (Krishna, 2002). 
International Journal of Trend in Scientific Research and Development (IJTSRD) ISSN: 2456-6470

Table 1. Effect of precision farming treatments on yield of tomato during rabi 2011

\begin{tabular}{|c|c|c|c|c|c|}
\hline Treatment details & $\begin{array}{l}\text { Plant } \\
\text { height } \\
\text { (cm) }\end{array}$ & $\begin{array}{l}\text { No. of } \\
\text { fruits/ } \\
\text { Plant }\end{array}$ & $\begin{array}{l}\text { Fruit } \\
\text { weight } \\
\text { (g) }\end{array}$ & $\begin{array}{l}\text { Plot } \\
\text { yield } \\
(\mathrm{kg})\end{array}$ & $\begin{array}{l}\text { Yield } \\
\text { / ha } \\
\text { (q) }\end{array}$ \\
\hline $\begin{array}{l}\text { T1. Raised bed + Drip irrigation + Plastic mulch + Fertigation + } \\
\text { Foliar spray of WSF (19:19:19@10g/lit. } 5 \text { times })+ \text { Mixture of } \\
\text { all micronutrients + C }\end{array}$ & 105.6 & 46.8 & 60.6 & 94.0 & 725.7 \\
\hline $\begin{array}{l}\text { T2. Raised bed + Drip irrigation + Plastic mulch + Fertigation + } \\
\text { Foliar spray of WSF (19:19:19@10g/lit. } 5 \text { times })+ \text { Mixture of } \\
\text { all micronutrients }\end{array}$ & 103.6 & 43.5 & 57.3 & 82.4 & 636.3 \\
\hline $\begin{array}{l}\text { T3. Raised bed + Drip irrigation + Plastic mulch + Fertigation }+ \\
\text { Foliar spray of WSF }(19: 19: 19 @ 10 \mathrm{~g} / \text { lit. } 5 \text { times })+\text { seedling } \\
\text { raised in tray }\end{array}$ & 100.7 & 41.5 & 54.6 & 75.0 & 579.1 \\
\hline $\begin{array}{l}\text { T4. Raised bed + Drip irrigation }+ \text { Plastic mulch }+ \text { Fertigation }+ \\
\text { Mixture of all micronutrients }+ \text { seedling raised in tray }\end{array}$ & 102. & 40.6 & 53.9 & 72.4 & 558.7 \\
\hline $\begin{array}{l}\text { T5. Raised bed + Drip irrigation + Plastic mulch + Foliar spray } \\
\text { of WSF (19:19:19@10g/lit. } 5 \text { times })+ \text { Mixture of all } \\
\text { micronutrients+ seedling raised in tray }\end{array}$ & 9 & 36.0 & 50.5 & 60.2 & 464.6 \\
\hline $\begin{array}{l}\text { T6. Raised bed + Drip irrigation + Fertigation + Foliar spray of } \\
\text { WSF }(19: 19: 19 @ 10 \mathrm{~g} / \text { lit. 5 times })+\text { Mixture of all } \\
\text { micronutrients }+ \text { seedling raised in tray }\end{array}$ & 100.1 & 40.0 & 53.6 & 70.5 & 544.0 \\
\hline T7. Farmer's practices & 88.4 & 38.4 & 53.2 & 67.8 & 523.1 \\
\hline $\mathrm{CD}(\mathrm{p}=0.05)$ & 2.04 & 2.04 & 1.29 & 3.74 & 18.89 \\
\hline Q co minernational vol & 4.19 & 5.89 & 5.35 & 4.90 & 4.90 \\
\hline
\end{tabular}

Table2. Effect of precision farming treatments on yield of tomato during rabi 2012

\begin{tabular}{|c|c|c|c|c|c|}
\hline Details & $\begin{array}{l}\text { Plant } \\
\text { heigh } \\
\text { t } \\
(\mathrm{cm})\end{array}$ & $\begin{array}{l}\text { No. } \\
\text { of } \\
\text { fruits } \\
\text { Plant }\end{array}$ & $\begin{array}{l}\text { Fruit } \\
\text { weight } \\
\text { (g) }\end{array}$ & $\begin{array}{l}\text { Plot } \\
\text { yield } \\
\text { (kg) }\end{array}$ & $\begin{array}{l}\text { Yield/ } \\
\text { ha (q) }\end{array}$ \\
\hline $\begin{array}{l}\text { T1. Raised bed + Drip irrigation + Plastic mulch + Fertigation + } \\
\text { Foliar spray of WSF }(19: 19: 19 @ 10 \mathrm{~g} / \mathrm{lit} .5 \text { times })+\text { Mixture of all } \\
\text { micronutrients }+ \text { seedling raised in tray }\end{array}$ & 106.5 & 46.4 & 62.7 & 83.8 & 776.0 \\
\hline $\begin{array}{l}\text { T2. Raised bed + Drip irrigation + Plastic mulch + Fertigation + } \\
\text { Foliar spray of WSF (19:19:19@10g/lit. } 5 \text { times) + Mixture of all } \\
\text { micronutrients }\end{array}$ & 103.4 & 44.8 & 59.2 & 76.4 & 707.0 \\
\hline $\begin{array}{l}\text { T3. Raised bed + Drip irrigation + Plastic mulch + Fertigation + } \\
\text { Foliar spray of WSF }(19: 19: 19 @ 10 \mathrm{~g} / \text { lit. } 5 \text { times })+\text { seedling } \\
\text { raised in tray }\end{array}$ & 101.8 & 43.1 & 55.3 & 68.6 & 636.0 \\
\hline $\begin{array}{l}\text { T4. Raised bed }+ \text { Drip irrigation }+ \text { Plastic mulch }+ \text { Fertigation }+ \\
\text { Mixture of all micronutrients }+ \text { seedling raised in tray }\end{array}$ & 102.8 & 41.3 & 54.7 & 65.1 & 602.0 \\
\hline $\begin{array}{l}\text { T5. Raised bed + Drip irrigation + Plastic mulch + Foliar spray of } \\
\text { WSF (19:19:19@10g/lit. 5 times })+ \text { Mixture of all } \\
\text { micronutrients }+ \text { seedling raised in tray }\end{array}$ & 94.2 & 30.7 & 40.3 & 35.6 & 330.0 \\
\hline $\begin{array}{l}\text { T6. Raised bed }+ \text { Drip irrigation }+ \text { Fertigation }+ \text { Foliar spray of } \\
\text { WSF (19:19:19@10g/lit. } 5 \text { times })+ \text { Mixture of all } \\
\text { micronutrients }+ \text { seedling raised in tray }\end{array}$ & 100.9 & 39.9 & 54.5 & 62.6 & 580.0 \\
\hline T7. Farmer's practices & 90.5 & 39.1 & 54.0 & 60.8 & 563.0 \\
\hline $\mathrm{CD}(\mathrm{p}=0.05)$ & 9.51 & 2.75 & 3.56 & 4.69 & 10.6 \\
\hline $\mathrm{CV} \%$ & 4.58 & 5.65 & 8.57 & 7.36 & 7.36 \\
\hline
\end{tabular}


International Journal of Trend in Scientific Research and Development (IJTSRD) ISSN: 2456-6470

Table 3. Effect of precision farming treatments on yield of tomato during rabi 2013

\begin{tabular}{|c|c|c|c|c|c|c|c|}
\hline Details & & & $\begin{array}{l}\text { Plan } \\
\text { height } \\
\text { t } \\
(\mathrm{cm})\end{array}$ & \begin{tabular}{c|c} 
No. \\
of \\
fruits \\
Plant
\end{tabular} & $\begin{array}{l}\text { Fruit } \\
\text { weight } \\
\text { (g) }\end{array}$ & $\begin{array}{l}\text { Plot } \\
\text { yield } \\
(\mathrm{kg})\end{array}$ & $\begin{array}{l}\text { Yield } \\
\text { / ha } \\
\text { (q) }\end{array}$ \\
\hline $\begin{array}{l}\text { T1. Raised bed + Drip irrigation + Plastic mulch } \\
\text { Foliar spray of WSF (19:19:19@10g/lit. } 5 \text { times }) \\
\text { micronutrients + seedling raised in tray }\end{array}$ & $\begin{array}{l}+ \text { Fertigat } \\
+ \text { Mixture }\end{array}$ & $\begin{array}{l}\text { ion }+ \\
\text { of all }\end{array}$ & 104.4 & 46.5 & 61.7 & 81.1 & 729.9 \\
\hline $\begin{array}{l}\text { T2. Raised bed + Drip irrigation + Plastic mulch } \\
\text { Foliar spray of WSF (19:19:19@10g/lit. } 5 \text { times) } \\
\text { micronutrients }\end{array}$ & $\begin{array}{l}+ \text { Fertigat } \\
+ \text { Mixture }\end{array}$ & $\begin{array}{l}\text { ion }+ \\
\text { of all }\end{array}$ & 102.3 & 44.2 & 58.9 & 76.9 & 692.1 \\
\hline $\begin{array}{l}\text { T3. Raised bed + Drip irrigation + Plastic mulch } \\
\text { Foliar spray of WSF (19:19:19@10g/lit. } 5 \text { tin } \\
\text { raised in tray }\end{array}$ & $\begin{array}{l}+ \text { Fertigat } \\
\text { nes) }+ \text { see }\end{array}$ & $\begin{array}{l}\text { ion }+ \\
\text { dling }\end{array}$ & 98.8 & 42.6 & 54.9 & 68.2 & 613.8 \\
\hline $\begin{array}{l}\text { T4. Raised bed + Drip irrigation }+ \text { Plastic mulch } \\
\text { Mixture of all micronutrients }+ \text { seedling raised in } \mathrm{tr}\end{array}$ & ay Fertigat & ion + & 99.7 & 41.5 & 53.6 & 65.8 & 592.2 \\
\hline $\begin{array}{l}\text { T5. Raised bed + Drip irrigation + Plastic mulch } \\
\text { WSF (19:19:19@10g/lit. 5 times) }+ \\
\text { micronutrients }+ \text { seedling raised in tray }\end{array}$ & $\begin{array}{l}\text { Foliar spr } \\
\text { lixture of }\end{array}$ & $\begin{array}{r}\text { ay of } \\
\text { all } \\
\end{array}$ & & & 39.5 & 35.9 & 323.1 \\
\hline $\begin{array}{l}\text { T6. Raised bed }+ \text { Drip irrigation + Fertigation + } \\
\text { WSF (19:19:19@10g/lit. 5 times) }+ \text { M } \\
\text { micronutrients }+ \text { seedling raised in traynternat }\end{array}$ & $\begin{array}{l}\text { Foliar spr } \\
\text { Tixture of }\end{array}$ & $\begin{array}{r}\text { ay of } \\
\text { all } \\
\end{array}$ & 98.3 & 39.5 & 55.4 & 63.3 & 569.7 \\
\hline T7. Farmer's practices & & & 87.7 & 38.8 & 51.9 & 59.6 & 536.4 \\
\hline $8 / 200110$ & & & 6.43 & 1.87 & 2.55 & 3.03 & 12.5 \\
\hline Y & $\mathrm{ArCh}$ & 101 & 8.69 & 6.89 & 7.36 & 8.64 & 8.64 \\
\hline$\frac{\text { ed mean data }}{\text { Treatments }}$ & & Yield & & & & & $\begin{array}{l}\text { e years } \\
\mathrm{BC} \text { ratio }\end{array}$ \\
\hline & $2010-11$ & 2011 & & & & & \\
\hline $\begin{array}{l}\text { T1. Raised bed + Drip irrigation + Plastic mulch + } \\
\text { Fertigation + Foliar spray of WSF }(19: 19: 19 \\
@ 10 \mathrm{~g} / \text { lit. } 5 \text { times })+ \text { Mixture of all micronutrients }+ \\
\text { seedling raised in tray }\end{array}$ & 725.7 & & & & 743.9 & & 3.07 \\
\hline $\begin{array}{l}\text { T2. Raised bed + Drip irrigation + Plastic mulch + } \\
\text { Fertigation + Foliar spray of WSF }(19: 19: 19 \\
\text { @ } 10 \mathrm{~g} / \text { lit. } 5 \text { times })+ \text { Mixture of all micronutrients }\end{array}$ & 636.3 & 707.0 & & 692.1 & 678.5 & & 2.58 \\
\hline $\begin{array}{l}\text { T3. Raised bed + Drip irrigation + Plastic mulch + } \\
\text { Fertigation }+ \text { Foliar spray of WSF }(19: 19: 19 \\
\text { @ } 10 \mathrm{~g} / \text { lit. } 5 \text { times })+ \text { seedling raised in tray }\end{array}$ & 579.1 & 636.0 & & 613.8 & 609.6 & & 2.25 \\
\hline $\begin{array}{l}\text { T4. Raised bed }+ \text { Drip irrigation }+ \text { Plastic mulch }+ \\
\text { Fertigation }+ \text { Mixture of all micronutrients }+ \text { seedling } \\
\text { raised in tray }\end{array}$ & 558.7 & 602.0 & & 592.2 & 584.3 & & 2.26 \\
\hline $\begin{array}{l}\text { T5. Raised bed + Drip irrigation + Plastic mulch }+ \\
\text { Foliar spray of WSF }(19: 19: 19 @ 10 \mathrm{~g} / \text { lit. } 5 \text { times })+ \\
\text { Mixture of all micronutrients }+ \text { seedling raised in tray }\end{array}$ & 464.6 & 330.0 & & 323.1 & 372.6 & & 1.55 \\
\hline $\begin{array}{l}\text { T6. Raised bed }+ \text { Drip irrigation }+ \text { Fertigation }+ \\
\text { Foliar spray of WSF }(19: 19: 19 @ 10 \mathrm{~g} / \text { lit. } 5 \text { times })+ \\
\text { Mixture of all micronutrients }+ \text { seedling raised in tray }\end{array}$ & 544.0 & 580.0 & & 569.7 & 564.6 & & 2.30 \\
\hline T7. Farmer's practices & 523.1 & 563.0 & & 536.4 & 540.8 & & 2.70 \\
\hline
\end{tabular}




\section{CONCLUSION}

From the above study, it could be concluded, that the pooled data of three years trials revealed that tomato var. COTH2 raised bed + drip irrigation + plastic mulch + fertigation + foliar spray of WSF $(19: 19: 19$ (a) $10 \mathrm{~g} /$ lit. 5 times) + Mixture of all micronutrients + seedlings raised in pro tray $(\mathrm{T} 1)$ recorded the highest plant height $(105.6 \mathrm{~cm})$, no. of fruits per plant (46.8), fruit weight $(60.6 \mathrm{~g})$, yield per plot $(94.0 \mathrm{~kg})$ and recorded the highest yield of $743.9 \mathrm{q} /$ ha with the BC ratio of 3.07 While the farmers practices, recorded the fruit yield of $540.8 \mathrm{q} / \mathrm{ha}$ with the $\mathrm{BC}$ ratio of 2.70 . Therefore (T1) raised bed + drip irrigation + plastic mulch + fertigation + foliar spray of WSF (19:19:19 (a) $10 \mathrm{~g} /$ lit. 5 times) + mixture of all micronutrients + seedling raised in pro trays can be recommended for getting increased growth, flowering and the highest yield for tomato under Rabi cultivation.

\section{Acknowledgement}

The author has been thankful to Department of Vegetables Crops, Horticultural College and Research Institute, Tamil Nadu Agricultural University, Coimbatore, for providing the Research Associate (Hort.) on AICRP-VC during the period of study.

\section{REFERENCES}

1. Asokaraja, N. 1998. Drip irrigation and mulching in tomato. In:Proc. Workshop on micro irrigation and sprinkler irrigation systems. New Delhi, Delhi.

2. Bar-Yosef, B. 1977. Trickle irrigation and fertigation of tomatoes in sand dunes: Water, N, and $\mathrm{P}$ distributions in the soil and uptake by plants. Agron. J., 69: 486-491.

3. Bracy, R.P., Edling, R.J. and E.B. Moser, E.B. 1995. Drip irrigation management and fertilization of bell pepper in humid areas. In: Proc. Fifth International micro irrigation congress, Florida, pp181-185.

4. Carrijo, O.A. and G. Hochmuth. 2000. Tomato responses to preplant incorporated or fertigated phosphorus on soils varying in Mehlieh 1 extractable phosphorus. Hort. Sci., 35(1): 67-72.

5. Anonymous. 2005. Fertilizer use by crop in Egypt, Food and Agriculture Organization of the United Nations. Rome, Italy.

6. Dass, H.C. 1985. In: proc. citrus shows cum seminar, R.F. Research Station, Abhor, pp12-16.
7. Deek, I.M., Battikhi, A.M. and S. Khattari. 1997.Effect of irrigation and $\mathrm{N}$ fertilization (fertigation) scheduling on tomato in the Jordan valley. J. Agron. and Crop Sci., 178(4): 205-209.

8. Dalvi, V.B., Tiwari, K.N., Pawade, M.N. and P.S. Phire. 1999.Response surface analysis of tomato production under micro irrigation. J. Water Mgmt., 41 (1): 11-19.

9. Gardenas, A.I., Hopman, J.W., Hanson, B.R. and J. Simunek. 2005.Two-dimensional modeling of nitrate leaching for various fertigation scenarios under micro-irrigation. J. Agric. Water Mgmt., 74(3): 219-242.

10. Haynes, R.J. 1985. Principles of fertilizer use for trickle irrigated crops. Ferti. Res., 6 (3): 235-255.

11. Hartz, T.K. and G.J. Hochmuth. 1996. Fertility management of drip irrigated vegetables. Hort. Tech., 6(3): 168.

12. Hugar, L.B. 1996. In: Proc. All India Seminar on Modern Irrigation Technologies, Bangalore, June 26-27. pp293-297.

13. Imamsahab, S.J., Patil, M.G., Naik, M.K., Hussain, Abbas S. and M.S. Ayyangoudar, 2011. Yield, yield components and quality of processing tomato (Solanum lycopersicum L.) genotypes as influenced by different levels of fertigation. Environ. \& Ecol., 29(1A): 229-232.

14. Koo, R.C. 1981. Effect of fertigation on yield of vegetable crops. Hort. Sci., 93: 33-36.

15. Krishna, M. 2002. Evaluation of capsicum hybrids and effect of source of fertilizers and levels of fertilization on its cultivation under green house condition, $\mathrm{Ph} \mathrm{D}$. Thesis, University of Agricuture Science, Bangalore, India.

16. Khan, M.M., Shivashankar, K., Krishna Manohar, R., Sree Rama, R. and Kasiyanna 1999. Fertigation in horticultural crops. In: Proc. Advances in micro irrigation and fertigation. Dharwad, pp181-197.

17. Natrajan, S., Sasikala, S. and G.R. Kumaresan. 2002. Influence of growing media, irrigation regime, integrated nutrient management and mulching on yield and economics in tomato (lycopersicon esculentum Mill) hybrids under polyhouse condition. S. Indian J. Hort., 53(1-6): 40-45. 
18. Payero, J.O., Bhangoo, M.S. and J.J. Steiner. 1990. Nitrogen fertilizer management practices to enhance seed production by Anaheiem chilli pepper. J. Amer. Soc. Hort. Sci., 115(2): 245-251.

19. Papadopoulos I. 1992. Nitrogen fertigation of trickle irrigated potatoes. Fert. Res., 31(1): 9-13.

20. Rao, C.S. 1996. Fertigation- Applying fertilizers through drip irrigation systems. In: Proc. of all India Seminar on modern Irrigation techniques, Bangalore, India.

21. Solaimalai, A., Baskar, M., Sadasakthi, A. and K. Subburamu. 2005. Fertigation in high value crops. Agric. Rev., 26(1): 1-13.

22. Satisha, G.C. 1997. Fertigation new concept in Indian agriculture. Kisan World, 24: 29-30.

23. Singandhupe, R.B., Rao, G.G., Patil. M.T. and P.S. Brahmanad. 2002. Fertigation studies and irrigation scheduling in drip irrigation system in tomato crop (Lycopersicon esculentus L.). Europe J. Agro., 19: $327-340$.
24. Sivanappan, R.K. 1996. Studies on the use of microirrigation system in crop production. Micro irrigation and fertigation. Ravi Publications, Bangalore. pp16-35.

25. Taha, M.H. 1999.Chemical fertilizers and irrigation system in Egypt. In: Proceedings of FAO regional workshop on guidelines for efficient fertilizers use through irrigation. Cairo, pp14-16.

26. Obreza, T.A. and C.S. Vavrina, C.S. 1995. Fertilization scheduling for improved nutrient use efficiency of micro-irrigated bell pepper in sandy soil. In: Proc. Dahha Greidinger International symposiumon fertigation, Israel, pp247-256.

27. Clark, G.A., Stanley, C.D., Maynard, D.N., Hochmuth, G.J., Hanlon, E.A. and D.Z. Haman. 1991. Water and fertilizer management of micro irrigated fresh market tomatoes. Trans. ASAE, 34(2): 429-435. 